Check for updates

1 University of Nottingham, Nottingham, UK

2 University of Manchester, Manchester, UK

3 De Montfort University, Leicester, UK

Correspondence to: $\mathrm{H}$ Sewell herb.sewell@nottingham.ac.uk

Cite this as: BMJ 2020;370:m3018 http://dx.doi.org/10.1136/bmj.m3018 Published: 31 July 2020

\title{
Cellular immune responses to covid-19
}

\section{T cells could be valuable allies in pandemic control}

\author{
Herb F Sewell, ${ }^{1}$ Raymond M Agius, ${ }^{2}$ Marcia Stewart, ${ }^{3}$ Denise Kendrick ${ }^{1}$
}

Protective and enduring immune responses to viral infections or vaccines usually arise from the combined actions of lymphocytes: B cells (responsible for humoral antibody immunity) and T cells (responsible for cellular immunity and helping B cell responses).

B cells produce detectable antibodies in classes IgM, IgG, and IgA along with lesser amounts of IgD and IgE. For SARS-CoV-2, the causative agent of covid-19, the focus is mainly on IgM, IgG, and IgA antibodies that can neutralise the virus by binding to the spike and other membrane proteins and thus preventing infection. ${ }^{1}$ Understanding the lesser known roles of T cells and cellular immunity will deepen our insights into covid-19 pathogenesis and help inform both vaccine development and pandemic containment strategies.

An effective immune response to SARS-CoV-2 involves four types or subsets of T cells: T helper cells (CD4) are responsible for cellular immunity and for helping B cells to produce neutralising antibodies; cytotoxic or killer T cells (CD8) directly kill infected cells-aided by helper T cells ${ }^{2}$; other T cells (including T-17 (Th17) cells) drive the inflammatory responses that help to control infections ${ }^{3}$; and regulatory $\mathrm{T}$ cells (T regs) help to contain the immune response, to prevent over-reaction and damage to tissues.

CD4 T cells ensure all these components work together by secreting small short acting cytokines that bind to receptors on target cells. Importantly, all $B$ and $T$ cell types have immunological memory after a first encounter with a pathogen. This enables a faster effective response after a second encounter with the same pathogen or one that is closely related (cross reaction).

Preliminary studies from the US and Europe recently documented T cells specific to SARS-CoV-2 in people with acute covid-19 and in those recovering from infection. . $^{-6}$ They report helper and killer T cells specific to SARS-CoV-2 in people with and without antibodies. ${ }^{6}$ More unexpectedly, they found specific $\mathrm{T}$ cells in people with no history of exposure to SARS-CoV-2-individuals who had repeatedly swabbed negative for the virus. ${ }^{4}$ These cells have even been found in stored blood taken before the pandemic (2015-18). Finally, the studies identified strong $\mathrm{T}$ cell memory responses in people recovering from covid-19. Memory cells are critical for protective and enduring immunity.

What are the implications of these early findings? Principally, these studies show that a good T cell immune response and immunological memory accompany natural exposure to or infection with SARS-CoV-2, that evidence of these responses is present in some people who have apparently never encountered the virus, and that $\mathrm{T}$ cell immune responses can exist in the absence of detectable antibodies.

Collectively, these features suggest that candidate vaccines ${ }^{7}$ should aim to stimulate both B cell (neutralising) antibodies and T cell antiviral responses. ${ }^{8}$ Early phase clinical trials of candidate vaccines developed in Oxford, UK, and in China do show concomitant B cell neutralising antibodies and antiviral T cells in vaccinated healthy volunteers, 910 improving prospects for protective immunity. This combined response is a feature of many successful vaccines, including vaccines against varicella (chickenpox), influenza, measles, and hepatitis B.

\section{Immune memory}

That some "virus naive" participants in early studies had pre-existing memory helper (50\% of participants) and killer $\mathrm{T}(20 \%)$ cells with potential activity against SARS-CoV-2 is intriguing. These cells might arise from cross reactions to other circulating coronaviruses, such as some common cold viruses, and might be a welcome hint of possible background immunity to covid-19 in populations at risk-even in the absence of antibodies.

Any cellular immune memory for SARS-CoV-2 in the population could enhance responses to vaccines and might also give a vaccination programme a head start towards herd immunity. Herd immunity is population resistance to spread of an infection, achieved when a high enough proportion of individuals are immune, usually through vaccination. ${ }^{11} 12$

Pre-existing memory helper T cells specific to SARS-CoV-2 could boost the production of neutralising IgG antibodies in the blood of newly exposed people and could also enhance antibody protection at mucosal surfaces through IgA in saliva, tears, or nasal secretions. ${ }^{13-15}$ Such IgA antibodies act as a protective barrier at common viral entry points. Research is now required to further characterise these possible immune pathways including memory B and T cells in mucosal tissues.

Research should also explore the role of regulatory $\mathrm{T}$ cells in severe covid-19, particularly cytokine storm syndrome ${ }^{16}$ and the documented association between high titres of IgG antibodies and poorer disease outcomes including death. ${ }^{17}$ Both might reflect ineffective control of inflammation by regulatory $\mathrm{T}$ cells.

Recent findings on the role of T cells in covid-19 give us cause to be cautiously optimistic that cellular immune responses could be a valuable ally in global efforts to control this and future pandemics. 
Competing interests: The BMJ has judged that there are no disqualifying financial ties to commercial companies. The authors declare the following other interests: None

Provenance and peer review: Commissioned, not peer reviewed

1 Walls AC, Park YJ, Tortorici MA, Wall A, McGuire AT, Veesler D. Structure, function, and antigenicity of the SARSCoV-2 spike glycoprotein. Cell 2020;181:281-292.e6. .

doi: 10.1016/j.cell.2020.02.058 pmid: 32155444

2 Ahrends T, Busselaar J, Severson TM, etal. $\mathrm{CD} 4^{+} \mathrm{T}$ cell help creates memory CD8 ${ }^{+} \mathrm{T}$ cells with innate and help-independent recall capacities. Nat Commun 2019;10:5531. doi: 10.1038/s41467-019-13438-1 pmid: 31797935

3 Bettelli E, Oukka M, Kuchroo VK. T(H)-17 cells in the circle of immunity and autoimmunity. Nat Immunol 2007;8:345-50. doi: 10.1038/ni0407-345 pmid: 17375096

4 Grifoni A, Weiskopf D, Ramirez SI, etal. Targets of T cell responses to SARS-CoV-2 coronavirus in humans with COVID-19 disease and unexposed individuals. Cell 2020;181:1489-1501.e15. doi: 10.1016/j.cell.2020.05.015 pmid: 32473127

5 Le Bert N, Tan AT, Kunasegaran K, et al. Different pattern of pre-existing SARS-COV-2 specific T cell immunity in SARS-recovered and uninfected individuals. BioRxiv [Preprint] https://www.biorxiv.org/content/10.1101/2020.05.26.115832v1

6 Sekine T, Perez-Potti A, Rivera-Ballesteros O, et al. Robust T cell immunity in convalescent individuals with asymptomatic or mild COVID-19. BioRxiv [Preprint] https://www.biorxiv.org/content/10.1101/2020.06.29.174888v1.

7 Caddy S. Developing a vaccine for covid-19. BMJ2020;369:m1790. doi: 10.1136/bmj.m1790 pmid: 32366511

8 Panagioti E, Klenerman P, Lee LN, van der Burg SH, Arens R. Features of effective T cell-inducing vaccines against chronic viral infections. Front Immunol 2018:9:276.

doi: 10.3389/fimmu.2018.00276 pmid: 29503649

9 Folegatti PM, Ewer KJ, Aley PK, etalOxford COVID Vaccine Trial Group. Safety and immunogenicity of the ChAdOX1 nCoV-19 vaccine against SARS-CoV-2: a preliminary report of a phase 1/2, single-blind, randomised controlled trial. Lancet 2020;. doi: 10.1016/S0140-6736(20)31604-4. pmid: 32702298

10 Zhu F-C, Guan X-H, Li Y-H, etal. Immunogenicity and safety of a recombinant adenovirus type-5-vectored COVID-19 vaccine in healthy adults aged 18 years or older: a randomised, double-blind, placebo-controlled, phase 2 trial. Lancet 2020; doi: 10.1016/S0140-6736(20)31605-6. pmid: 32702299

11 Britton T, Ball F, Trapman P. A mathematical model reveals the influence of population heterogeneity on herd immunity to SARS-CoV-2. Science 2020; doi: 10.1126/science.abc6810. pmid: 32576668

12 Lourenço J, Pinotti F, Thompson C, Gupta S. The impact of host resistance on cumulative mortality and the threshold of herd immunity for SARS-CoV-2. MedRxiv [Preprint]. https://www.medrxiv.org/content/10.1101/2020.07.15.20154294V1.

13 Strugnell RA, Wijburg OLC. The role of secretory antibodies in infection immunity. Nat Rev Microbiol 2010;8:656-67. doi: 10.1038/nrmicro2384 pmid: 20694027

14 Brandtzaeg P. Secretory IgA: designed for anti-microbial defense. Front Immunol 2013;4:222. doi: 10.3389/fimmu.2013.00222 pmid: 23964273

15 Zhao J, Zhao J, Mangalam AK, etal. Airway memory CD4(+) T cells mediate protective immunity against emerging respiratory coronaviruses. Immunity 2016:44:1379-91. doi: 10.1016/j.jmmuni.2016.05.006 pmid: 27287409

16 Blanco-Melo D, Nilsson-Payant BE, Liu WC, etal. Imbalanced host response to SARS-CoV-2 drives development of covid-19. Cell 2020;181:1036-1045.e9. doi: 10.1016/j.cell.2020.04.026 pmid: 32416070

17 Zhao J, Yuan Q, Wang H, etal. Antibody responses to SARS-CoV-2 in patients of novel coronavirus disease 2019. Clin Infect Dis 2020: . doi: 10.1093/cid/ciaa344 pmid: 32221519

This article is made freely available for use in accordance with BMJ's website terms and conditions for the duration of the covid-19 pandemic or until otherwise determined by BMJ. You may use, download and print the article for any lawful, non-commercial purpose (including text and data mining) provided that all copyright notices and trade marks are retained. 